\title{
Identical Legal Entities and the Trinity: Relative-Social Trinitarianism
}

\author{
James Goetz \\ Independent Scholar
}

\begin{abstract}
Goetz outlined legal models of identical entities that include natural persons who are identical to a coregency and natural persons who are identical to a general partnership. Those entities cohere with the formula logic of relative identity. This essay outlines the coexistence of relative identity and numerical identity in the models of identical legal entities, which is an account of impure relative identity. These models support the synthesis of Relative Trinitarianism and Social Trinitarianism, which I call Relative-Social Trinitarianism.
\end{abstract}

\section{Introduction}

Goetz (2014) outlined two categories of identical legal entities. The first category is an undivided natural person who is multiple public officials. The second category is multiple natural persons who are an undivided entity such as a general partnership or a customary coregency. ${ }^{1}$ This essay proposes that the second category is useful for Trinitarian theology. For example, Tertullian (c. 145-220) and Gregory of Nazianzus (c. 325-391) compared the unity of the Father, Son, and Holy Spirit to the unity of a coregency. Also, models of identical legal entities help to synthesize Relative Trinitarianism (RT) and Social Trinitarianism (ST). I call this Relative-Social Trinitarianism (RST).

RT and ST are contemporary philosophical accounts of Trinitarianism. Basic descriptions for RT and ST follow. RT uses the logic of relative identity to explain the threeness-oneness paradox of the Trinity (Van Inwagen 2011); ST in various ways defend that the Father, Son, and Holy Spirit are three divine persons who enjoy interpersonal relationships with each other while they are one God (Hasker 2014).

RT also divides into two primary categories that are (1) pure RT and (2) impure RT. Additionally, this paper proposes a unique model of impure RT that includes Trinitarian analogy and merges that model with ST.

1 The descriptions of (1) a general partnership and (2) a customary coregency are strange because they are unlike most entities and cohere to the formula logic of relative identity outlined in section 3. For example, " $x$ and $y$ are the same $F$, but $x$ and $y$ are different $G$ s." Also, one might suppose that a general partnership or a customary coregency is a collective entity, but that is a misconception.

Journal of Analytic Theology, Vol. 4, May 2016

$$
\text { 10.12978/jat.2016-4.181919061425a }
$$

(C) 2016 James Goetz • (C) 2016 Journal of Analytic Theology 
In the rest of this essay, section 2 summarizes the definitions and metaphysics of legal entities; section 3 models the coexistence of numerical identity and relative identity in cases of legal entities; section 4 analyzes Leibniz's Law; section 5 introduces identical entities and RST; section 6 analyzes RT; section 7 analyzes an objection to ST; section 8 concludes with a brief discussion of the Gospel of John and the fourth-century creeds.

\section{Legal entities and metaphysical entities}

This section defines respective legal terminology and the metaphysics of natural law entities.

\subsection{Contemporary definitions of legal entities and metaphysical entities}

Three primary types of contemporary legal entities are (1) a geopolitical entity, (2) a natural person, and (3) a juristic entity. Also, the term legal entity is synonymous with legal person. Additionally, in the context of natural law theory and metaphysics, each case of a legal entity is also a concrete entity.

First, a geopolitical entity is a geographical area with a political structure while the entity acts with autonomy. The typical contemporary geopolitical entity is a sovereign state defined by the international Convention on Rights and Duties of States (1933). For example, Article 1 says: "The state as a person of international law should possess the following qualifications: a ) a permanent population; b ) a defined territory; c ) government; and d) capacity to enter into relations with the other states." Also, Article 4 says: "States are juridically equal, enjoy the same rights, and have equal capacity in their exercise. The rights of each one do not depend upon the power which it possesses to assure its exercise, but upon the simple fact of its existence as a person under international law."

Typical attributes of geopolitical entities include the following:

1. A typical geopolitical entity has public departments.

2. A department could be a geographical division or an administrative division.

3. Legislation can make any department into a juristic entity.

4. Any department can have its own departments.

5. Each department has its distinct governmental authority.

6. All departments have public officials.

7. The officials are natural persons who are inseparable from their public office and likewise identical to their office.

Second, a natural person is a freeborn human who possesses rights and duties. The primary right is the right to own property. Also, natural persons are inseparable from their property. Similarly, a natural person who owns an unincorporated 
proprietorship is inseparable from the proprietorship and likewise identical to the proprietorship.

Third, a juristic entity is a public department or a private business other than an unincorporated proprietorship (Deiser 1908; 1909a; 1909b). A public juristic entity is made from legislation. A private juristic entity is made in accordance with legislation. All juristic entities possess rights and duties derived from legislation while the primary right is the right to own property. Also, synonymous terms for juristic entity include juristic person, juridical entity, juridical person, artificial entity, artificial person, fictitious entity, and fictitious person.

Fourth, legal fiction refers to judicial court assumptions apart from legislation. For example, legal fiction says that all judicial entities, general partnerships, and natural persons have equal standing as a claimant or defendant. However, the equal standing in court is limited outside of court and never granted any juristic entity or general partnership the right to vote in any public election.

Fifth, the definitions in the above first to fourth are standard for all schools of legal philosophy while this paragraph defines the terms abstract and concrete in the context of natural law theory. I simply intend a generic contrast for concrete and abstract. For example, the concept of a legal entity is an abstract entity while an individual legal entity is a concrete entity. For instance, the French Republic is a legal entity and a concrete entity. Also, a natural person is a legal entity and a concrete entity. Other examples of concrete entities include cases of (1) a territory, (2) a population of residents, (3) a government, (4) a public department, (5) a public official, and (6) property. Additionally, I use the term physical entity, which is a concrete entity that foremost derives its existence from the fundamental forces of physics.

\subsection{Outline of Key Historical Developments}

The first legal entities might have been Middle Paleolithic / Middle Stone Age tribunals that deliberated customary rules to settle disputes about movable property. For example, starting 100,000 years ago, highly sophisticated technologies began to sporadically emerge and disappear. This might have coincided with the first deliberations of customary tribunals to settle disputes about ownership and trade of food and technology. Eventually, highly sophisticated technologies began to perpetuate 50,000 years ago during the advent of the Upper Paleolithic / Later Stone Age. This also included the ownership of clothing and movable shelter. Likewise, Upper Paleolithic developments of movable property had prompted the perpetuation of tribunals that settled disputes about ownership.

Geopolitical entities first emerged around 10,500 years ago after the invention of agriculture that prompted the Neolithic Era / New Stone Age. In a sense, the first geopolitical entity was the first farm with permanent residents and a defined territory. For example, every farm has some form of management, which is a form of government. Also, the first farm with permanent residents and defined territory was not a geopolitical division, so this was an autonomous government. However, when 
neighboring farms developed and prompted the formation of a municipality, then the first farm became a mere proprietorship unless the proprietor was also the ruler of the municipality. Eventually, cities and then kingdoms emerged. The customary kingdoms included natural persons, public officials, proprietors, and geopolitical departments.

Around 2,000 BCE, contracts for loans began to emerge in the Ancient Near East. Ancient Rome codified the existence of juristic entities. Roman juristic persons included tribunals, provinces, cities, towns, religious bodies, associations of government officials, associations of commercial proprietors, social associations, and universities, but they did not include the Roman Empire.

Finally, the modern era codified the existence of coexisting sovereign states, intellectual property, private corporations, unincorporated limited liability corporations, and other types of private business entities.

\section{Section 2.3 Metaphysics of legal entities}

This subsection summarizes the metaphysics of geopolitical entities and respective parts.

A geopolitical entity has a defined territory, a permanent population, and a government. The territory and population are tangible parts while the government is an intangible part. This indicates that a geopolitical entity is a tangible-intangible dualistic entity. Also, all legal entities with tangible parts are a dualistic entity.

The intangible nature of government is extraordinarily plastic. For example, the primary government of a geopolitical entity and its departments are distinct while they nonetheless coincide with each other.

Contemporary consensus of legal scholars advances that natural law theory helps to explain the metaphysics of intangible government. A dissenting minority such as legal positivists reject the existence of natural law, which this paper calls natural law anti-realism. For example, natural law theorists accept the existence of natural rights while natural law anti-realists reject the existence of natural rights. For instance, natural law theory advances that a natural person's right to own property is natural while natural rights anti-realism advances that a natural person's right to own property is an artificial construction. Similarly, natural law theory advances that the origin of government and political officials was natural while a natural rights antirealist advances that all government and political officials are an artificial construction. Also, natural law theory advances that some juristic persons such a city are natural.

Goetz (2014) proposes a natural law theory for the unity of legal entities based on the self-organization of social animals and organic precursors of natural rights. The theory coheres with both deontology and consequentialism.

Regarding self-organization, measurable patterns of self-organization and collective behavior among social vertebrates include (1) schools of fish, (2) flocks of birds, (3) herds and flocks of ungulate mammals, (4) human crowds, and (5) basic leadership and followership among fish, birds, ungulates, primates, and human 
crowds. For example, self-organization is a process that involves numerous interactions among local-level components of a system that cause the emergence of a global-level pattern in space and time. These measurable patterns suggest the reality of organic social organization among various vertebrates that first emerged and perpetuated since the Paleozoic Era (542 to 252 million years ago). This organic social organization is also a major component of all geopolitical entities.

Also, Hermann Haken (2008) pioneered research that indicates selforganization occurs in many fields of natural science, social science, and technology. Likewise, self-organization exists in every nook and cranny of the universe.

More phenomena comparable to the self-organization of social vertebrates include empirical evidence that indicates many primate populations develop complex social systems. Also, material evidence from the Neolithic Era / New Stone Age suggests that humans who develop farming technology possess an organic tendency to form the custom of a geopolitical entity.

Regarding natural rights, a basic natural right is the right to own movable property. An organic precursor to the ownership of movable property was animals that constructed and protected nests. The animals include species of insects, fish, amphibians, reptiles, birds, and mammals. This ubiquitous construction and protection of nests has resemblance to property ownership because the nests belong to the particular animals. In the cases of nest building birds and mammals, empirical evidence indicates that hormones regulate the nesting instinct. Also, the organic management of rudimentary stone tools in the Lower Paleolithic / Earlier Stone Age (2.6 million to 300 thousand years ago) by hominids had resemblance to movable property ownership because the stone tools belonged to the hominids. Additionally, the Lower Paleolithic management of stone tools was an organic precursor to the property ownership in the previously mentioned Upper Paleolithic. These organic phenomena suggest that property ownership is natural. Furthermore, the right to own property is an international custom.

The ubiquitous evidence of self-organization and organic precursors of property ownership suggests that geopolitical entities with all of their moral faults and virtues are foremost naturally organized. This natural organization also suggests that intangible governmental authority is a physical entity. For example, as previously defined, a physical entity is foremost derived from the fundamental forces of physics. Consider also the following summary of evidence that supports the physical existence of intangible authority:

Despite the intangible nature of government, research of past and current phenomena indicates strong evidence that legal persons sometimes generate enormous force. Great nations rise and fall. Government officials declare war and armies fight with tangible weapons. Legal entities buy and sell property. Universities grant academic degrees. A cartoon character is intangible property that generates multibillions of US dollars per year. Banks and law enforcement foreclose mortgages of family residences. Governments 
and economies around the world operate according to the logic of law. (Goetz 2014)

This natural law theory supports that intangible government and concomitant intangible authority generate enormous physical force. This also indicates the extraordinary plasticity of intangible authority. For example, legislation enables a private corporation to make an abstract concept of a cartoon character into intellectual property that generates multibillions of US dollars per years.

\section{Section 2.4 Special cases of general partnerships and coregencies}

In the context of natural law theory, this paper and subsection focus on the puzzling metaphysics of general partnerships and coregencies. For example, a general partnership is multiple natural persons who are the same legal entity. Also, a coregency is multiple joint monarchs who are the same monarchical office. For the rest of this paper, a customary coregency is simply called a coregency.

A general partnership is a type of unincorporated proprietorship. For example, sole proprietorships and general partnerships are ancient customs. A sole proprietorship is naturally inseparable from the sole proprietor who is the respective natural person. The proprietor has all authority and all liability of the business, which indicates that the proprietor is identical to the proprietorship. Comparatively, a general partnership has multiple proprietors called general partners who each have all authority and all liability of the business, which indicates that each general partner is identical to the partnership.

Various interlocutors have confused general partnerships with the legislative fiction of private corporations and limited liability companies. However, general partnerships as well as sole proprietorships are formed without legislation and have no limits on liability while private corporations and limited liability companies are formed in accordance with legislation that makes fictitious separation between the owners and their businesses. This fictitious separation is appealing because it limits liability. Likewise, there is a major difference between a general partnership and a limited liability partnership. Also, the fictitious separation is an ongoing controversy in the news while lawyers and judges never question if a private corporation or a limited liability company is a legal person.

In the case of judicial court, legal fiction grants equal standing as a claimant or defendant to any natural person, general partnership, or juristic entity. Also, the court never entertains any differences of opinion about the realism or anti-realism of legal entities. ${ }^{2}$

Cases of coregency compare to general partnerships because a coregency is multiple natural persons who each are the same entity and the same authority. A monarch or coregency is not technically a legal entity, but each case is a physical entity.

\footnotetext{
${ }^{2}$ For example, a shrewd lawyer who is a natural law anti-realist, mereological nihilist, or global skeptic might dazzle the courts with brilliant arguments while feigning belief in the reality of all laws.
} 
Also, an absolute monarch or absolute coregency might not be defined as a public office but is nonetheless office-like.

Notable ancient examples of coregencies include the following:

1. Some Egyptian Pharaohs appointed their successor to joint ruler in a senior-junior relationship with identical authority (Dodson 2014).

2. Some Egyptian Pharaohs appointed their wife to joint ruler with identical authority (Dodson 2014).

3. King David near the end of his life appointed Solomon to joint monarch (1 Chronicles 29).

4. The Roman Senate in 44 BCE appointed the triumvirate of Octavian, Marcus Lepidus, and Mark Antony while each of the triumvirs enjoyed absolute authority that was restrained only by a term limit.

5. The Roman Senate in $13 \mathrm{CE}$ appointed Octavian and Tiberius to identical office.

Consider the case of the 44-33 BCE monarchical-like triumvirate of Octavian, Lepidus, and Antony. Each triumvir enjoyed the same absolute authority that was restrained only by a term limit. Octavian was identical to the triumvirate; Lepidus was identical to the triumvirate; Antony was identical to the triumvirate; Octavian, Lepidus, and Antony were different natural persons.

\section{The coexistence of numerical identity and relative identity}

The majority of analytic philosophers hold to classical logic while supporting that everything in the universe coheres with the concept of numerical identity (NI) that is defined by Leibniz's Law (LL). Alternatively, Geach $(1967 ; 1969 ; 1977)$ rejected the existence of NI while proposing relative identity (RI). Additionally, Gupta (1980) proposed an in-between view that accepts some cases of NI and some cases of RI. The rest of this section looks at the coexistence of $\mathrm{NI}$ and RI in mathematical equality and legal models of identical entities.

The term $N I$ is also synonymous with the term absolute identity. Additionally, $\mathrm{NI}$ is typically defined by Leibniz's Law (LL) that states the following:

(LL) $x$ is identical to $y$ indicates that for every property $F$, entity $x$ has $F$ if and only if entity $y$ has $F$.

In other words, LL states that no two distinct things possess the same properties and no other properties.

Alternatively, the formula logic of RI states the following:

(RI) $x$ and $y$ are the same $F$, but $x$ and $y$ are different $G$ s. 
The formula indicates that $x$ is identical to $F$; $y$ is identical to $F ; x$ and $y$ are different entities. A notable characteristic of RI is the existence of identicalness without absolute identicalness and similar biconditionality. For example, RI indicates the following: $x$ is identical to $F$, but not $x$ if and only if $F$; $y$ is identical to $F$, but not $y$ if and only if $F ; x$ is not identical to $y$. One might suspect that transitivity would indicate that $x$ is identical $y$, but that is not the case with RI.

The coexistence of NI and RI indicates that the terms identical and same need contextual clarification. For example, two things that are identical could be numerically identical or relatively identical. Or two things that are the same could be numerically same or relatively same.

Abstract examples of relative identity include applications of mathematical equality. For example, Presocratic philosophers defined mathematical equality. Also, Quine's (1960, chapter 7) mathematical realism indicates that expressions, variables, numbers, and values are abstract entities. For instance, consider $A=B$. This equation indicates that the variables $A$ and $B$ possess numerically identical value while the variables are different entities. In the case of the RI formula,

$$
x=A ; y=B ; F=\text { value; } G \mathrm{~s}=\text { variables } .
$$

The formula indicates the following:

1. $A$ is relatively identical to the value, but not $A$ if and only if the value.

2. $B$ is relatively identical to the value, but not $B$ if and only if the value.

3. The value of $A$ if and only if the value of $B$.

4. $A$ is not identical to $B$.

Consider also the following expressions $1+3$ and $2+2$. The expressions possess numerically identical value that is 4 while the expressions are different entities. In the case of the RI formula,

$$
x=1+3 ; y=2+2 ; F=\text { value; } G \text { s }=\text { expressions }
$$

The formula indicates the following:

1. The expression $1+3$ is relatively identical to the value 4 , but not $1+$ 3 if and only if 4 .

2. The expression $2+2$ is relatively identical to the value 4 , but not $2+$ 2 if and only if 4 .

3 . The value of $1+3$ if and only if the value of $2+2$.

4. The expression $1+3$ is not identical to the expression $2+2$.

Identical legal entities also cohere with the formula logic of RI (Goetz 2014, 45-46). Consider the following cases from section 2: (1) a natural person who is a public official, (2) a general partnership, and (3) a coregency. 
First case, natural person Lepidus became the triumvir and the pontifex maximus. Lepidus was the triumvir while Lepidus was the pontifex maximus. However, the triumvir and the pontifex maximus were different entities. In the case of the RI formula,

$x=$ the triumvir; $y=$ the pontifex maximus;

$F=$ natural person; $G$ s = public entities.

The formula indicates the following:

1. The triumvir was relatively identical to Lepidus, but not the triumvir if and only if Lepidus.

2. The pontifex maximus was relatively identical to Lepidus, but not the pontifex maximus if and only if Lepidus.

3. Lepidus who existed as the triumvir if and only if Lepidus who existed as the pontifex maximus.

4. The triumvir was not identical to the pontifex maximus.

Second case, natural persons $\mathrm{X}$ and $\mathrm{Y}$ become proprietors while forming general partnership C. $\mathrm{X}$ is $\mathrm{C}$ and possesses the entire authority of $\mathrm{C}$; $\mathrm{Y}$ is $\mathrm{C}$ and possesses the entire authority of $\mathrm{C}$; $\mathrm{X}$ and $\mathrm{Y}$ are different natural persons. In the case of the RI formula,

$x=\mathrm{X} ; y=\mathrm{Y} ; F=$ general partnership C; Gs = natural persons.

The formula indicates the following:

1. $\mathrm{X}$ is relatively identical to $\mathrm{C}$, but not $\mathrm{X}$ if and only if $\mathrm{C}$.

2. $\mathrm{Y}$ is relatively identical to $\mathrm{C}$, but not $\mathrm{Y}$ if and only if $\mathrm{C}$.

3. X's authority of $\mathrm{C}$ if and only if Y's authority of C.

4. $\mathrm{X}$ is not identical to $\mathrm{Y}$.

Third case, Octavian, Lepidus, and Antony were natural persons who became triumvirs of the second triumvirate. Octavian was the triumvirate and possessed absolute authority; Lepidus was the triumvirate and possessed absolute authority; Antony was the triumvirate and possessed absolute authority; Octavian, Lepidus, and Antony were different natural persons. In the case of the RI formula,

$x=$ Octavian; $y=$ Lepidus; $z=$ Antony;

$F=$ the second triumvirate; $G$ s = natural persons.

The formula indicates the following:

1. Octavian was relatively identical to the triumvirate, but not Octavian if and only if the triumvirate. 
2. Lepidus was relatively identical to the triumvirate, but not Lepidus if and only if the triumvirate.

3. Antony was relatively identical to the triumvirate, but not Antony if and only if the triumvirate.

4. Octavian's absolute authority if and only if Lepidus's absolute authority.

5. Octavian's absolute authority if and only if Antony's absolute authority.

6. Lepidus's absolute authority if and only if Antony's absolute authority.

7. Octavian was not identical to Lepidus.

8. Octavian was not identical to Antony.

9. Lepidus was not identical to Antony.

The if and only if statements in the RI cases indicate the coexistence of relative identicalness and numerical identicalness, which indicates the coexistence of RI and NI. This coexistence indicates impure RI and impure NI, which are synonymous terms. Alternatively, Geach's RI that rejects all reality of NI is pure RI while classical logic supports pure NI. Additionally, I propose a straightforward law of temporal identity that states the following:

Anything is absolutely identical to itself and nothing else at any given point of time.

Impure RI and impure NI also contain multiplication and addition. For example, each of the $G$ s is equivalent to the number 1 . In the case for the number of $F$, the expression with each of the $G$ s uses multiplication. In the case for the number of $G$ s, the expression with each of the $G$ s uses addition. Consider the triumvirate and triumvirs:

The number of triumvirates $=1 \times 1 \times 1$.

The number of triumvirs $=1+1+1$.

\section{Analysis of LL}

Per the previously stated law of temporal identity, NI indicates that an entity is absolutely identical to itself at any given point of time. However, classical logicians typically reject that LL and NI always mean that an entity is absolutely the same to itself in the case of change. Consider LL that was previously stated:

(LL) $x$ is identical to $y$ indicates that for every property $F$, entity $x$ has $F$ if and only if entity $y$ has $F$.

LL indicates that $F$ is a set of properties that is contained in $x$ and contained in $y$, but classical expressions of NI over time indicate that $F$ is something other than the set of 
all properties for the same tangible entity at two distinguishable points of time. For instance, the field of physics indicates that a Planck time is the smallest possible unit of measurement for time in a physical universe while all elementary particles change their position from one Planck time to the next, so every tangible entity changes its composition from any given Planck time to the next. Also, absolute sameness breaks down from change, which is a propositional tautology. Consider also the following case of human $\mathrm{N}$ over time.

Human $\mathrm{N}$ possesses different properties for any given point of time to the next distinguishable point of time. Consider $\mathrm{N}$ represented in a four-dimensional spacetime coordinate system. Each point in a spacetime coordinate system is assigned three spatial dimensions and one time dimension. $\mathrm{N}$ at point of time $0\left(\mathrm{NT}_{0}\right)$ and $\mathrm{N}$ at point of time $1\left(\mathrm{NT}_{1}\right)$ are not identical compositions when the difference in time between $\mathrm{NT}_{0}$ and $\mathrm{NT}_{1}$ is at least 1 Planck time because $\mathrm{N}$ at bare minimum has a change in the position of all elementary particles. Likewise, $\mathrm{NT}_{0} \neq \mathrm{NT}_{1}$ in the context of composition while $\mathrm{NT}_{0}=\mathrm{NT}_{1}$ in the context of identity. Absolute sameness indisputably breaks down during the passage of time from $\mathrm{NT}_{0}$ to $\mathrm{NT}_{1}$ because $\mathrm{NT}_{0}$ and $\mathrm{NT}_{1}$ possess a different set of properties. Nonetheless, the identity of any legal entity such as a natural person endures all nonessential changes to the entity. In this case of $\mathrm{N}$, no classical logician would suggest that $\mathrm{NT}_{0}$ if and only if $\mathrm{NT}_{1}$.

Consider the two most popular replies by analytic philosophers to the puzzle of identity over time and change (Deutsch 2012). In the case of $\mathrm{NT}_{0}$ and $\mathrm{NT}_{1}$, the two most popular replies would follow: reply 1, simple properties that are different between $\mathrm{NT}_{0}$ and $\mathrm{NT}_{1}$ are actually relations to times and have nothing to do with identity; reply 2 , the differences between $\mathrm{NT}_{0}$ and $\mathrm{NT}_{1}$ are distinct temporal parts or stages of the whole temporally extended $\mathrm{N}$ and have nothing to do with identity. These replies in one way or another indicate that $F$ in LL is a subset of properties for $\mathrm{NT}_{0}$ and $\mathrm{NT}_{1}$. Also, replies 1 and 2 cohere with the formula logic of RI. Per reply $1, \mathrm{NT}_{0}$ is $x$; $\mathrm{NT}_{1}$ is $y$; $\mathrm{N}$ is $F$; different relations of times for $\mathrm{N}$ are $G \mathrm{~s}: \mathrm{NT}_{0}$ and $\mathrm{NT}_{1}$ are the same $\mathrm{N}$ while $\mathrm{NT}_{0}$ and $\mathrm{NT}_{1}$ are different relations of times for $\mathrm{N}$. Per reply $2, \mathrm{NT}_{0}$ is $x ; \mathrm{NT}_{1}$ is $y$; $\mathrm{N}$ is $F$; different temporal parts or stages for $\mathrm{N}$ are $G$ s: $\mathrm{NT}_{0}$ and $\mathrm{NT}_{1}$ are the same $\mathrm{N}$ while $\mathrm{NT}_{0}$ and $\mathrm{NT}_{1}$ are different temporal parts or stages of $\mathrm{N}$.

The classical replies are creative while expressing LL despite change over time. But classical logic faces problems with cases of identical entities. For example, section 2 indicates the following five facts regarding the second triumvirate:

F1. There was one second triumvirate.

F2. Octavian was identical to the triumvirate and possessed absolute authority.

F3. Lepidus was identical to the triumvirate and possessed absolute authority.

F4. Antony was identical to the triumvirate and possessed absolute authority.

F5. Octavian, Lepidus, and Antony were different natural persons. 
I doubt that any creative expression of LL could cohere with F1-F5. For example, LL could cohere with F1-F4 while rejecting F5 and state that Octavian, Lepidus, and Antony were not different natural persons. Or LL could reject F1 while cohering with F2-F5 and state that there were three second triumvirates. But LL evidently lacks the flexibility to cohere with F1-F5. Additionally, rejecting F1 or F5 is historically false because F1-F5 is historically true. Alternatively, RI in section 3 coheres with F1-F5.

\section{Legal models of identical entities and the Trinity}

Legal models of identical entities can analogize the medieval Shield of the Trinity that summarizes the threeness-oneness paradox in the Athanasian Creed. For example, the Shield of the Trinity makes that following six propositions:

1. The Father is God and vice versa.

2. The Son is God and vice versa.

3. The Holy Spirit is God and vice versa.

4. The Father is not the Son and vice versa.

5. The Father is not the Holy Spirit and vice versa.

6. The Son is not the Holy Spirit and vice versa.

Analogizing the Athanasian definition of the Trinity to a general partnership indicates that the Father, Son, and Holy Spirit are general partners while the triune God is the general partnership. Also, analogizing the Trinity to a coregency indicates that the Father, Son, and Holy Spirit are joint monarchs while the triune God is the coregency. In both analogies, the Father is the triune God; the Son is the triune God; the Holy Spirit is to the triune God; the Father and Son are different unipersonalities; the Father and Holy Spirit are different unipersonalities; the Son and Holy Spirit are different unipersonalities. This indicates that the Father, Son, and Holy Spirit are three unipersonalities who are one triune God.

Remarkable properties of the general partnership and coregency analogies include that the analogies cohere with Relative Trinitarianism (RT) and Social Trinitarianism (ST) while the synthesis of RT and ST is Relative-Social Trinitarianism (RST). For example, the Trinitarian analogies cohere with ST because multiple persons of an identical entity can enjoy interpersonal relationships with each other. Also, the Trinitarian analogies cohere with RT because they cohere with the RI formula.

In the case of the RI formula and the Trinitarian analogies,

$x=$ the Father; $y=$ the Son; $z=$ the Holy Spirit;

$F=$ the triune God; $G s$ = unipersonalities.

The formula indicates that the Father, Son, and Holy Spirit are the same triune God while the Father, Son, and Holy Spirit are different divine unipersonalities. Additionally, 
1. The Father is relatively identical to the triune God, but not the Father if and only if the triune God.

2. The Son is relatively identical to the triune God, but not the Son if and only if the triune God.

3. The Holy Spirit is relatively identical to the triune God, but not the Holy Spirit if and only if the triune God.

4. The Father's divine authority if and only if the Son's divine authority.

5. The Father's divine authority if and only if the Holy Spirit's divine authority.

6. The Son's divine authority if and only if the Holy Spirit's divine authority.

7. The Father is not identical to the Son.

8. The Father is not identical to the Holy Spirit.

9. The Son is not identical to the Holy Spirit.

One might challenge that the general partnership and coregency analogies of the Trinity support tritheism instead of monotheism. However, in the case of a general partnership, regardless of the number of general partners who individually enjoy the entire authority of the general partnership, there is always one concrete general partnership. Or regardless of the number of joint monarchs who individually enjoy the entire authority of any coregency, there is always one concrete coregency. Likewise, in the case of God, each of the three divine persons and any combination of them are always one God who is one authority.

Any analogy of God, however, needs qualifications. For example, the term analogy indicates similarities and dissimilarities.

Biblical authors routinely analogized God to the legal concepts of king and judge. However, God is dissimilar to a king or judge. For example, all natural persons who become a king or judge had a beginning while God exists with no beginning. Moreover, some biblical analogies are astonishingly dissimilar to God. For instances, Isaiah 31:5 compares God to a flock of birds and Luke 18:1-8 compares God to an unrighteous judge.

In any case, philosophy and theology requires careful qualification for all analogies of God. Consider the following two sets of dissimilarities between the Trinity and identical legal entities.

First, the dissimilarities of the Trinity compared to identical legal entities include:

1. The Trinity exists without beginning or end.

2. The Trinity is divine substance.

3. The Trinity is inexhaustible love and incorruptibility.

4. The Trinity is inexhaustible perception.

5. The Father, Son, and Holy Spirit possess equal levels of ability.

6. The Father, Son, and Holy Spirit always see and act with unity. 
Second, the dissimilarities of identical legal entities compared to the Trinity include:

1. General partnerships and coregencies emerge from previously separate natural persons and potentially terminate.

2. General partnerships and coregencies are made of legal authority.

3. General partnerships and coregencies possess human love and corruptibility.

4. General partnerships and coregencies possess limited perception.

5. General partners or joint monarchs might possess unequal levels of ability.

6. General partners or joint monarchs might see and act with disunity.

\section{Relative Trinitarianism}

Rea (2011a) categorizes RT into pure RT and impure RT. Pure RT assumes pure RI and impure RT assumes impure RI. Geach $(1967 ; 1969)$ originally proposed pure RI, and Geach (1977, 72-81) outlined pure RT. Other proponents of pure RT include Martinich (1978; 1979) and Cain (1989). Alternatively, van Inwagen (2011) and this essay propose impure RT.

Rea (2011a) objects to all versions of pure RT because they indicate antirealism of NI. Rea also objects to van Inwagen's RT because van Inwagen supposedly never makes a clear acceptance for the reality of NI. However, he explicitly rejects all nontheological models of RI, which at first glance suggests that he accepts the reality of NI. Also, van Inwagen (1993) defends classical logic in the case of the material world. In any case, section 3 of this essay models the coexistence of NI and RI, which helps to resolve Rea's objection to RT.

I appreciate Martinich's (1979) model of pure RT that incorporates Tertullian's analogy of coregency. However, I disagree with the pure RT. Also, another nuance between our models is that Martinich never uses the term coregency while he says that two simultaneous emperors are the same emperor.

Rea (2011a) also insists that impure RT must tell a non-heretical story:

Thus, for example, telling a story according to which Father, Son, and Holy Spirit can be the same God but different Persons in just the same way that two cars can be the same color but different cars clearly will not do the job.

Consider the story of a red Porsche and a red Jaguar. This coheres with the RI formula logic while $x$ is the red Porsche; $y$ is the red Jaguar; $F$ is the color red. In this case, the color red is an abstract entity. Likewise, stating that the Porsche is relatively identical to the color red while the Jaguar is relatively identical to the color red does not satisfy Rea's intuitions about the metaphysics of the Trinity. Perhaps Rea objects because theism assumes that God is a concrete entity who is not comparable to an abstract entity such as the color red. Also, mathematical modeling of equations in section 3 
involves abstract entities. Nonetheless, the general partnership and coregency analogies refer to concrete examples of general partnership and concrete examples of coregency. For example, the concept of a coregency is an abstract entity while the triumvirate of Octavian, Lepidus, and Antony was a concrete coregency.

\section{An Objection to Social Trinitarianism}

As previously stated, various models of ST defend that the Father, Son, and Holy Spirit are three divine persons who enjoy interpersonal relationships with each other while they are one God. At face value, these interpersonal relationships are consistent with the Son praying to the Father per the Gospels (for examples, Matthew 26:39; Mark 14:16; Luke 22:41-42; John 17). However, critics of ST object to the prevalent ST view that the Father, Son, and Holy Spirit share one general divine nature instead of one concrete divine nature (Rea 2011b).

Despite the prevalent ST view of general divine nature, Hasker (2014) proposes ST and one concrete divine nature. I agree with the objection to a general divine nature while that prevalent ST view is unnecessary for RST. Also, the identical entities analogies for the Trinity include one concrete authority, which plausibly corresponds to the divine substance.

Additionally, van Inwagen in personal communication to Hasker (2014, chapter 15) mentioned belief in interpersonal relationships between the three divine persons. This indicates that his impure RT is compatible with ST and likewise RST.

\section{Discussion on the Gospel of John and fourth-century creeds}

The Oxford Bible Commentary (accessed 24-Dec-2014) says that the prologue for the Gospel of John, which is John 1:1-18, explicitly states that Jesus is "identical" to the "Word" referenced in John 1:1-4. For example,

In the beginning was the Word, and the Word was with God, and the Word was God. He was in the beginning with God. All things came into being through him, and without him not one thing came into being. What has come into being in him was life, and the life was the light of all people. (John 1:1-4, New Revised Standard Version)

....

And the Word became flesh and lived among us, and we have seen his glory, the glory as of a father's only son, full of grace and truth. (John testified to him and cried out, "This was he of whom I said, 'He who comes after me ranks ahead of me because he was before me.'") From his fullness we have all received, grace upon grace. The law indeed was given through Moses; grace and truth came through Jesus Christ. No 
one has ever seen God. It is God the only Son, who is close to the Father's heart, who has made him known. (John 1:14-18, NRSV)

This prologue sets the stage for the entire Gospel of John. For examples, John assumes monotheism; John 1:1-18 says that Jesus is the Word who in the beginning was with God and generated all creation; John 14:16-17 says that the Holy Spirit is another Advocate who is comparable to Jesus; John 17 records Jesus praying to the Father in the context of an I-you interpersonal relationship, which means that Jesus refers to himself as "I" and to the Father as "you."

These Johannine concepts plausibly indicate the following points:

J1. There is one God.

J2. The Father is God.

J3. The Son is equal to God.

J4. The Holy Spirit is equal to God.

J5. The Father, Son, and Holy Spirit are different persons who enjoy interpersonal relationships with each other.

The collection of these Johannine concepts is consistent with the fourth-century creeds, the Shield of the Trinity, and RST. Alternatively, the collection of these concepts is inconsistent with classical identity that is defined by LL. But the creeds, Shield of the Trinity, RST, and LL were undefined during the first-to-second-century authorship of John. However, during that time, inhabitants of the Roman Empire were familiar with general partnerships and coregencies. Also, educated inhabitants of the Roman Empire were familiar with mathematical expressions and values, Aristotelian law of identity, and the debate about identity over time for tangible objects that change such as Theseus's Ship (Goetz 2014).

Tertullian in the early third century tied together these Johannine concepts with his threeness-oneness model of monotheism when he developed an outstanding analogy between coregency and God. He made this analogy while opposing modalism advocated by Praxeas and Sabellius. For example, Tertullian (1885) said:

I am sure that Monarchy has no other meaning than single and individual rule; but for all that, this monarchy does not, because it is the government of one, preclude him whose government it is, either from having a son, or from having made himself actually a son to himself, or from ministering his own monarchy by whatever agents he will. Nay more, I contend that no dominion so belongs to one only, as his own, or is in such a sense singular, or is in such a sense a monarchy, as not also to be administered through other persons most closely connected with it, and whom it has itself provided as officials to itself. If, moreover, there be a son belonging to him whose monarchy it is, it does not forthwith become divided and cease to be a monarchy, if the son also be taken as a sharer in it; but it is as to its origin equally his, by whom it is 
communicated to the son; and being his, it is quite as much a monarchy (or sole empire), since it is held together by two who are so inseparable.

Martinich (1979) said that Tertullian referred to the 161-169 Roman coregency of Marcus Aurelius and Lucius Versus. Also, Tertullian might have known about earlier examples listed in section 2 of this paper.

Gregory of Nazianzus's (1885) oration "On the Son" also made a comparison between coregency and God. Gregory is a prominent fourth-century church father and was a champion of Trinitarian theology, but his coregency analogy was brief and there is no other surviving record of a coregency analogy from any other fourth-century church father. For example, the Council of Nicea (325) and the Council of Constantinople (381) made no use of this analogy while the councils outlined the threeness-oneness of God while focusing on the eternal generation of the Son and the eternal procession of the Holy Spirit, which implies that the generation and procession exists beyond time and likewise without beginning or end. In any case, the coregency and general partnership analogies are compatible with the respective creeds. ${ }^{3}$

\section{Bibliography}

Cain, James. 1989. "The Doctrine of the Trinity and the Logic of Relative Identity." Religious Studies 25 (2): 141-52. DOI: http://dx.doi.org/10.1017/S0034412500001761.

Convention on Rights and Duties of States. 1933. http://avalon.law.yale.edu/20th_century/intam03.asp.

Deiser, George F. 1908. "The Juristic Person: I." University of Pennsylvania Law Review and American Law Register 57 (3): 131-142, http://www.jstor.org/stable/3313312. . 1909a. "The Juristic Person: II." University of Pennsylvania Law Review and American Law Register 57 (4): 216-235, http://www.jstor.org/stable/3313929. . 1909b. "The Juristic Person: III." University of Pennsylvania Law Review and American Law Register 57 (5): 300-314, http://www.jstor.org/stable/3313740.

3 I thank the blind reviewer at JAT, blind reviewers from previous submissions, Dale Tuggy and interlocutors on his blog, Michael Rea, and Robin Parry for important comments about the concepts that I developed in this paper. I also thank Trent Dougherty for mediating the multiple steps of the review and revision process. 
Deutsch, Harry. 2012. "Relative Identity," In Stanford Encyclopedia of Philosophy, edited by Edward N. Zalta, http://plato.stanford.edu/archives/win2008/entries/identity-relative/.

Dodson, Aidan. 2014. "The Coregency Conundrum." Kmt: A Modern Journal of Ancient Egypt 25 (2): 29-35.

http://www.academia.edu/8204701/The_Coregency_Conundrum.

Geach, Peter Thomas. 1967. "Identity." The Review of Metaphysics 21 (1): 3-12. http://www.jstor.org/stable/20124493.

. 1969. "Geach and Relative Identity: A Reply." The Review of Metaphysics 22 (3): 556-559. http://www.jstor.org/stable/20124879. . 1977. The Virtues. Cambridge University Press.

Goetz, James. 2014. "Natural Unity and Paradoxes of Legal Persons." The Journal Jurisprudence 21: 27-47. http://www.jurisprudence.com.au/juris21/Goetz.pdf.

Gregory of Nazianzus. 1885. "Oration 29: On the Son." Translated by Charles Gordon Browne and James Edward Swallow. In Cyril of Jerusalem, Gregory Nazianzen, In Nicene and Post-Nicene Fathers, edited by Philip Schaff and Henry Wace. http://www.ccel.org/ccel/schaff/npnf207.iii.xv.html.

Gupta, Kumar Anil. 1980. The Logic of Common Nouns: An Investigation in Quantified Modal Logic. Yale University Press.

Haken, Hermann. 2008. "Self-organization." Scholarpedia 3 (8): 1401. http://www.scholarpedia.org/article/Self-organization.

Hasker, William. 2014. Metaphysics and the Tri-Personal God. Oxford: Oxford University Press. DOI: 10.1093/acprof:oso/9780199681518.001.0001.

Martinich, Aloysius Patrick. 1978. "Identity and Trinity." The Journal of Religion 58 (2): 169-181. http://www.jstor.org/stable/1201874. 1979. "God, Emperor, and Relative Identity." Franciscan Studies 39:180-191.

Quine, Willard Van Orman. 1960. Word and Object. MIT Press.

Rea, Michael. C. 2011a. "Relative Identity and the Doctrine of the Trinity." In Philosophical and Theological Essays on the Trinity, edited by Thomas McCall and Michael C. Rea, chapter 13, Oxford University Press. DOI: 10.1093/acprof:oso/9780199216215.003.0013. 
. 2011b. "The Trinity." In The Oxford Handbook of Philosophical Theology, edited by Thomas P. Flint and Michael C. Rea, Oxford University Press. DOI: 10.1093/oxfordhb/9780199596539.013.0019.

Tertullian. 1885. Against Praxeas. Translated by Peter Holmes. In Latin Christianity: Its Founder, Tertullian, edited by Allan Menzies. In Ante-Nicene Fathers edited by Philip Schaff. http://www.ccel.org/ccel/schaff/anf03.i.html.

Van Inwagen, Peter. 1993. "Precis of Material Beings." Philosophy and Phenomenological Research 53 (3): 683-686. http://www.jstor.org/stable/2108092. 2011. "And yet they are not three Gods but one God." In Philosophical and Theological Essays on the Trinity, edited by Thomas McCall and Michael C. Rea, chapter 12, Oxford University Press. DOI: 10.1093/acprof:oso/9780199216215.003.0012. 